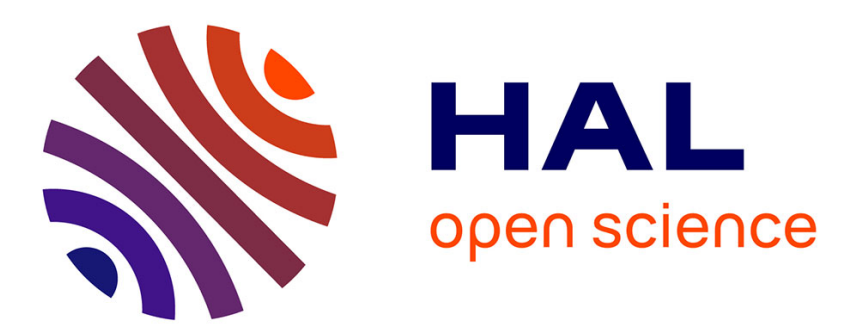

\title{
Effect of household and industrial processing on levels of pesticide residues and degradation products in melons
}

\author{
Aurore Bonnechère, Vincent Hanot, Claude Bragard, Thomas Bedoret, Joris
} van Loco

\section{- To cite this version:}

Aurore Bonnechère, Vincent Hanot, Claude Bragard, Thomas Bedoret, Joris van Loco. Effect of household and industrial processing on levels of pesticide residues and degradation products in melons. Food Additives and Contaminants, 2012, 29 (7), pp.1058-1066. 10.1080/19440049.2012.672339 . hal00811703

\section{HAL Id: hal-00811703 https://hal.science/hal-00811703}

Submitted on 11 Apr 2013

HAL is a multi-disciplinary open access archive for the deposit and dissemination of scientific research documents, whether they are published or not. The documents may come from teaching and research institutions in France or abroad, or from public or private research centers.
L'archive ouverte pluridisciplinaire HAL, est destinée au dépôt et à la diffusion de documents scientifiques de niveau recherche, publiés ou non, émanant des établissements d'enseignement et de recherche français ou étrangers, des laboratoires publics ou privés. 


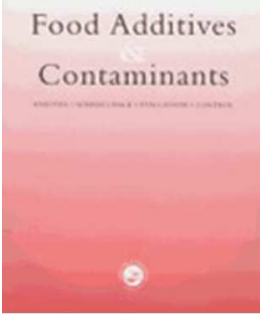

\section{Effect of household and industrial processing on levels of pesticide residues and degradation products in melons}

\begin{tabular}{|c|c|}
\hline Journal: & Food Additives and Contaminants \\
\hline Manuscript ID: & TFAC-2011-530.R1 \\
\hline Manuscript Type: & Original Research Paper \\
\hline Date Submitted by the Author: & 20-Feb-2012 \\
\hline Complete List of Authors: & $\begin{array}{l}\text { Bonnechère, Aurore; Scientific Institute of Public Health, Pesticides } \\
\text { Hanot, Vincent; Scientific Institute of Public Health, } \\
\text { Bragard, Claude; Faculté d'ingénierie biologique, agronomique et } \\
\text { environnementale UCL, } \\
\text { Bedoret, Thomas; Redebel, } \\
\text { Van Loco, Joris; Scientific Institute of Public Health, }\end{array}$ \\
\hline Methods/Techniques: & LC/MS, GC \\
\hline Additives/Contaminants: & Pesticide residues \\
\hline Food Types: & Fruit, Vegetables \\
\hline Abstract: & $\begin{array}{l}\text { Two varieties of melons (Cucumis melo) were treated by two fungicides } \\
\text { (carbendazim and maneb) and four insecticides (acetamiprid, cyromazin, } \\
\text { imazalil and thiamethoxam) to quantify the effect of household processing } \\
\text { on the pesticide residues. To ensure sufficiently high levels of residues in } \\
\text { flesh and peels, the most concentrated formulations were applied pursuant } \\
\text { to Good Agricultural Practices (GAPs). The peeling step decreased the } \\
\text { concentration of pesticide residues for maneb, imazalil and acetamiprid by } \\
\text { more than } 90 \% \text {. Cyromazin, carbendazim and thiamethoxam were reduced } \\
\text { by } 50 \% \text {. The reduction of the pesticides could not be fully explained by } \\
\text { the systemic character of the pesticides. However, the agricultural } \\
\text { practices (time of application), the solubility and mode of action (systemic } \\
\text { vs. contact pesticide) of the pesticides allowed to make assumptions to } \\
\text { explain the difference in processing factors for the studied pesticides. } \\
\text { Degradation products (melamine and ethylenethiourea) were also } \\
\text { investigated in this study but were not detected. }\end{array}$ \\
\hline
\end{tabular}




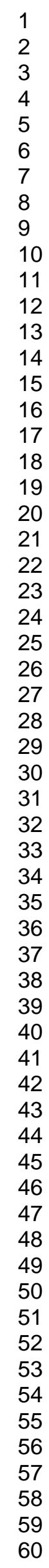

SCHOLARONE ${ }^{m}$

Manuscripts

25

26

27
28

29

30

32

33

34

35

36

37

38

39

40

42

43

44

45

46

47

48

50

51

52

53

54

55

57

58

59

60

http://mc.manuscriptcentral.com/tfac Email: fac@tandf.co.uk 
1 Effect of household and industrial processing on levels of pesticide residues

2 and degradation products in melons

3

4

5

6

7

8

Aurore Bonnechère ${ }^{\mathrm{a}}$, Vincent Hanot ${ }^{\mathrm{a}}$, Claude Bragard ${ }^{\mathrm{b}}$, Thomas Bedoret ${ }^{\mathrm{c}}$ and Joris Van Loco $^{a}$

${ }^{a}$ Food, Medicines and Consumer Safety Department, Scientific Institute of Public Health, Rue Juliette Wytsman 14, BE-1050 Ixelles, Belgium

${ }^{b}$ Earth \& Life Institute, Applied Microbiology-Phytopathology, Université Catholique de Louvain, Croix du Sud 2, L7.05.03, BE-1348 Louvain-la-Neuve, Belgium

${ }^{c}$ Redebel sa, Rue de Chassart 4, 6221 Saint-Amand

Corresponding author: Vincent Hanot

Tel.: 00322/642.51.89

Fax: 00322/642.56.91

Email address: vincent.hanot@wiv-isp.be

Postal address: Rue Juliette Wytsman 14, BE-1050 Ixelles, Belgium

\section{Abstract}

Two varieties of melons (Cucumis melo) were treated by two fungicides (carbendazim and maneb) and four insecticides (acetamiprid, cyromazin, imazalil and thiamethoxam) to quantify the effect of household processing on the pesticide residues. To ensure sufficiently high levels of residues in flesh and peel, the most concentrated formulations were applied observing Good Agricultural Practice (GAP). The peeling step decreased the concentration of pesticide residues for maneb, imazalil and acetamiprid by more than $90 \%$. Cyromazin, carbendazim and thiamethoxam were reduced by $\sim 50 \%$. The reduction of the pesticides could not be fully explained by the systemic character of the pesticides. However, the agricultural practices (time of application), solubility and mode of action (systemic vs. contact pesticide) of the pesticides could be used to explain the difference in processing factors for the studied 
1 pesticides. Degradation products (melamine and ethylenethiourea) were also investigated in

2 this study but were not detected.

3

4 Keywords: Pesticide residues, Processing factor, Fungicides, Insecticides, Degradation 5 products

\section{$7 \quad$ Introduction}

8 Melon (Cucumis melo) belongs to the same family as the cucumber, squash, pumpkin and 9 gourd and grows on the ground on a trailing vine. It is a sweet, juicy and very nutritious fruit. 10 The major producing countries are China (which produces more than $50 \%$ of the world 11 production), Turkey, Iran, Spain, the United States, Rumania, Egypt and India (FAO, 2011).

12 This crop is susceptible to fusarium wilt disease (destructive vascular disease), downy mildew 13 (killing plants prematurely and reducing sugar content of melons) and gummy stem blight 14 (lesion on stems and leaves). To protect plants particularly during autumn growing seasons 15 and avoid these type of diseases, fungicide applications are necessary (Keinath et al. 2007, 16 Zhao et al. 2011). Furthermore, insecticides on melons are necessary to suppress high 17 whitefly populations and aphids (Tong-Xian 2004).

18 Pesticides have been linked to a wide spectrum of human health hazards, ranging from 19 short-term impacts such as headaches and nausea to chronic impacts like cancer, reproductive 20 harm, and endocrine disruption. Chronic health effects may occur years after even minimal 21 exposure to them in the environment, or result from their residues ingested through food and 22 water (Berrada et al. 2010, Claeys et al. 2011, Keikotlhaile et al. 2010). Research focuses on 23 the proper use of pesticides in terms of authorization and registration and on compliance with 24 Maximum Residue Limits (MRLs). Given the potential risk of pesticides for public health, the 25 use of pesticides in agriculture is subjected to constant monitoring. (Chen et al. 2011, Claeys 2 
1 et al., 2011). It is important for the consumer to know the intake of pesticide residues. The

2 processing factors (PF: ratio between residues concentration in the processed commodity and

3 the same in the raw commodity) are useful to estimate the level of pesticide exposure at the

4 point of consumption after processing (Ling et al. 2011). Until now, no processing factors are

5 available for melons. However, melon consumption is increasing in the EU (AND

6 International 2010). Indeed, among the EU 27, the volumes of import of melons increased

$7 \quad$ twofold between 1999 and 2008.

8 It is well known that peeling plays a role in the reduction of residues (Holland et al. 1994,

9 Kaushik et al. 2009, Timme et al. 2004). Several studies of peeling have been done on

10 potatoes to measure some pesticides and minimum $90 \%$ reduction of pesticide residues were

11 observed (Kaushik et al. 2009, Lentza-Rizos et al. 2001, Lewis et al. 1996, Randhawa et al.

12 2007, Schattenberg et al. 1996). The peeling of apples, tomatoes, peppers, carrots, bananas,

13 oranges and lemons were also investigated in several studies (Balinova et al. 2006, Burchat et

14 al. 1998, Chavarri et al. 2005, Rasmusssen et al. 2003, Timme \& Walz-Tylla 2004). In these

15 experiments, peeling decreased residues (70 to 100\%). However, some pesticides were not

16 influenced by this process because of their systemic activity (Krol et al. 2000).

17 Melons, frequently consumed in Belgium, were chosen in cooperation with the Belgian

18 Federal Agency for Safety of the Food Chain (FASFC). Pesticides were chosen according to

19 their frequency of MRL exceedance, frequency of detection and their toxicity (FASFC 2007,

20 FASFC 2008). Selected pesticides included acetamiprid, carbendazim, cyromazin, imazalil,

21 maneb and thiamethoxam.

22 To establish of processing factors for these pesticide residues, melons were grown, 23 sprayed, harvested, peeled, homogenized and analyzed. The selected pesticides and the 24 degradation products (ETU from maneb and melamine from cyromazin) were analysed before 25 and after peeling with several analytical methods (GC-MS/MS, GC-ECD, UHPLC-MS/MS). 
3 Materials and Methods

$4 \quad$ Materials

$5 \quad$ Pesticides

6 Deuterated ethylenethiourea $\left(\mathrm{d}_{4}\right.$-ETU), ethylenethiourea, carbendazim and acetamiprid 7 were purchased from Dr. Ehrenstorfer GmbH (Augsburg, Germany) with certified purity of $899.0 \%$. Thiram, cyromazin, melamine, imazalil and thiamethoxam were purchased from

9 Sigma-Aldrich (Seelze, Germany) with certified purity of $99.0 \%, 99.9 \%, 99.0 \%, 99.8 \%$ and $1099.7 \%$, respectively. Carbon disulfide (99.9\%) was obtained from Merck (Darmstadt, 11 Germany).

Chemicals for analysis

14 Ultrapure water $(<8 \mathrm{M} \Omega \cdot \mathrm{cm}$ resistance) was supplied by a Millipore purification system 15 (Millipore Milli-Q Water System, Bedford, USA). Methanol, dichloromethane and 16 acetonitrile were of HPLC grade from Biosolve (Valkenswaard, The Netherlands). Iso-octane, 17 sodium hydroxide and ammoniac (25\%) came from Merck (Darmstadt, Germany). 18 Trifluoroacetic acid (TFA) and acid acetic (with certified purity of at least $99 \%$ for both) as 19 well as ammonium acetate were purchased from Aldrich (Steinheim, Germany). Hydrochloric 20 acid (37\%) and tin(II)-chloride were obtained from VWR (Fontenay sous Bois, France). 21 Ethanol (96\%), ammonium chloride (99.5\%), celite ${ }^{\circledR}$ 545, sodium sulphate (99\%) and sodium 22 chloride (99\%) were purchased from VWR (Leuven, Belgium).

23 The stock solution of carbon disulfide $\left(\mathrm{CS}_{2}\right)$, for analysis of maneb, was prepared at $4 \mathrm{mg}$ $24 \mathrm{~mL}^{-1}$ in iso-octane. Dilute standards at $40 \mu \mathrm{g} \mathrm{mL}^{-1}$ were prepared by dilution of the stock 
1 solution with iso-octane. A solution of thiram was prepared with ethanol to obtain an 2 equivalent concentration in $\mathrm{CS}_{2}$ of $63.23 \mathrm{mg} \mathrm{L}^{-1}$.

3 The stock solutions of acetamiprid, carbendazim, cyromazin, imazalil and thiamethoxam 4 for LC-MS/MS were prepared at $1 \mathrm{mg} \mathrm{mL}^{-1}$ in acetonitrile containing $0.1 \%$ of acetic acid.

5 Dilute standards at $10 \mu \mathrm{g} \mathrm{mL}^{-1}, 1 \mu \mathrm{g} \mathrm{mL}^{-1}$ and $100 \mathrm{ng} \mathrm{mL}^{-1}$ were prepared by dilution of the 6 stock solution with methanol.

7 The stock solution of internal standard, ETU D4, was prepared at $100 \mu \mathrm{g} \mathrm{mL}^{-1}$ in 8 methanol. The stock solution of ETU was prepared at $1 \mathrm{mg} \mathrm{mL}^{-1}$ in methanol. Dilute 9 standards were prepared by dilution of the stock solution with water.

10 The stock solution of melamine was prepared at $1 \mathrm{mg} \mathrm{mL}^{-1}$ in $\mathrm{NaOH} 0.1 \%$. Dilute 11 standards at $10 \mu \mathrm{g} \mathrm{mL}^{-1}$ and $1 \mu \mathrm{g} \mathrm{mL}^{-1}$ were prepared by dilution of the stock solution with 12 water.

13 Solutions for calibration were prepared with spiking of diluted standard solution on blank 14 extract of melon. The blank extract came from melons previously tested in which no 15 pesticides were detected above the limit of detection. All solutions were stored at $-18{ }^{\circ} \mathrm{C}$.

16

17

\section{Produce}

\section{Cultivation}

The purpose of the field experiment was to produce in parallel two different melons varieties, Mohican and Pancha, exposed to six selected pesticides.

Field melon was grown at Villers-Perwin, Belgium by Redebel sa. under greenhouse conditions. Four applications of pesticides were performed on different crop growth stages as shown in Table 1. The concentrations of the six active substances and the number of applications were as high as possible, but following the GAPs (pre-harvest time, time between two applications...), to ensure sufficiently high pesticide levels for the effects of processing 
1 practices to be studied. It should be noted that some pesticides are not approved for the melon

2 crops in Belgium but are in other countries. The formulations were applied in two passing

3 using vertical spraying boom equipment at the proposed normal settings and timing.

4

5 Harvest

6 Fruit specimens were taken manually. Sterile disposable (nitrile) gloves were worn for the 7 sampling. The first and the last plants of plot, diseased and undersized fruits were excluded 8 from sampling. To obtain more than $70 \mathrm{~kg}$ of melons, 67 melons Pancha and 103 melons

9 Mohican were randomly collected from the whole plot. A number identified each variety.

10 Melons were stored in a refrigerator room at $4{ }^{\circ} \mathrm{C}$ directly after the sampling. They were 11 transported in refrigerated condition to the laboratory on the day of harvest.

\section{Overview of processing and sampling steps}

15 Figure 1 shows the sampling flow diagram. To minimize the factor of variability, the two 16 melon varieties were each divided into two batches of $18 \mathrm{~kg}$ of raw melons, giving four 17 batches in total (Figure 1). As shown in Figure 1, part of melons did not undergo any 18 processing and was used as "positive control sample". Peeling step for all batches was executed on the same day.

At each step, melons were homogenized and $500 \mathrm{~g}$ were collected and stored at $-20{ }^{\circ} \mathrm{C}$ 21 until pesticide residue analysis. Frozen samples were analyzed within one month.

\section{Unprocessed melon}

24 These melons, which did not undergo any processing are the "positive control sample". It 25 is the raw melon used to calculate the PFs. The harvested melons (18 kg of melons taken 6 
1 randomly) were cut into pieces and comminuted with the Robot Coupe ${ }^{\circledR}$ R23 (Mont-Saint-

2 Genevieve, Belgium). A sample was taken after a rough cut $(\sim 1 \mathrm{~cm})$ and frozen for the

3 analysis of mancozeb. The rest was comminuted for a longer time and frozen until analysis.

4

$5 \quad$ Peeling

6 The peeling was realised with a knife with a blade of $10 \mathrm{~cm}$ and corresponded to the 7 peeling done by the consumer at home. We left the green part on the peels $(<0.5 \mathrm{~cm})$. Melons

8 Mohican were smaller than melons Pancha but both varieties were highly variegated.

9 After removal of the peels, flesh (about $10 \mathrm{~kg}$ ) and peels (about $7 \mathrm{~kg}$ ) were comminuted separately with the Robot Coupe ${ }^{\circledR}$ R23 (Mont-Saint-Genevieve, Belgium) and frozen until analysis.

\section{Extraction and analysis of pesticides}

Analysis of maneb by GC-ECD

The analysis of maneb as $\mathrm{CS}_{2}$ (compound obtained when dithiocarbamates are heated in presence of acid and tin chloride) is based on methods normalized by the European Committee for Standardization and modified by de Kok to replace the existing headspace chromatography method by a liquid injection in GC-ECD (de Kok 2001, European Committee for Standardization 1998).

The extraction of $25 \mathrm{~g}$ of matrix was done in presence of hydrochloric acid, iso-octane and tin chloride. A closed vessel was stirred during $2 \mathrm{~h}$ in a water bath at $80{ }^{\circ} \mathrm{C}$. After cooling, 1 $\mu \mathrm{l}$ of the supernatant containing $0.28 \mathrm{~g}$ matrix per $\mathrm{mL}$ was injected on a Varian 3400 gas chromatographic system coupled with a ${ }^{63} \mathrm{Ni}$ Electron Capture Detector and a Varian $8200 \mathrm{C}$ autosampler. The GC separation of $\mathrm{CS}_{2}$ was achieved on a DB-5 column $(60 \mathrm{~m}, 0.53 \mathrm{~mm}$ and $1.5 \mu \mathrm{m}$ ) from Grace (Deerfield, USA). The helium gas flow was at $2.6 \mathrm{~mL} \mathrm{~min}^{-1}$ at 5 psi. The 7 
1 injector and detector temperatures were $250{ }^{\circ} \mathrm{C}$ and $300{ }^{\circ} \mathrm{C}$, respectively. The column

2 temperature was at $50{ }^{\circ} \mathrm{C}$ for $5 \mathrm{~min}$, after that it increased by $50{ }^{\circ} \mathrm{C}$ per min until $250{ }^{\circ} \mathrm{C}$. This

3 temperature was maintained for $5 \mathrm{~min}$ to obtain a total run time of $19 \mathrm{~min}$. The retention time 4 of $\mathrm{CS}_{2}$ was $3.3 \mathrm{~min}$.

5

6 Analysis of acetamiprid, carbendazim, cyromazin, imazalil and thiamethoxam by LC-MS/MS

7 This method followed the Granby principle (Granby et al. 2004) with some adaptations. A

$810 \mathrm{~g}$ sample of melons was extracted with a mixture of an extraction solvent $(5 \mathrm{mM}$

9 ammonium acetate, $90 \% \mathrm{MeOH}-10 \%$ water), blended during 1 min with an ultra-turrax

10 homogenizer (Ultra-turrax IKA) and filtrated on büchner. Oxfendazole, the internal standard

11 was added to the filtrate. Mixture of extraction was used to give an extract volume of $60 \mathrm{~mL}$.

12 The raw extract was diluted with mobile phase $\mathrm{A}(10 \% \mathrm{MeOH}, 1 \%$ ammonium acetate $0.5 \mathrm{M}$

13 and $89 \%$ water) to a final concentration equivalent to $0.1 \mathrm{~g}$ matrix per $\mathrm{mL}$ and injected after

14 filtration on $0.2 \mu \mathrm{m}$. The LC separation was achieved on an Acquity UPLC BEH $\mathrm{C}_{18}$ column

$15(1.7 \mu \mathrm{m}, 2.1 \times 100 \mathrm{~mm})$ from Waters (Ireland). A gradient of mobile phase A and mobile

16 phase B (containing $10 \%$ water, $1 \%$ ammonium acetate $0.5 \mathrm{M}$ and $89 \%$ of methanol) supplied

17 at $0.45 \mathrm{~mL} \mathrm{~min}^{-1}$ was applied. Starting from $99.9 \%$ of mobile phase A, the mobile phase was

18 linearly increased to $99.9 \%$ of mobile phase B in 10 min and maintained during two min. The

19 gradient was then returned to initial conditions in $0.1 \mathrm{~min}$ and held there for 2.9 min for 20 stabilization. The mass spectrometer operated in a positive electrospray ionization (ESI) mode 21 and acquired two transitions for each pesticide. Typical optimized ESI voltage settings are 22 presented in Table 2. Argon was used as the collision gas at a setting of $0.35 \mathrm{~mL} \mathrm{~min}{ }^{-1}$. The 23 dwell time was $10 \mathrm{~ms}$ per channel for quantifier ions and $5 \mathrm{~ms}$ for second transition. 
1 The method of analysis is described in a paper of Bonnechère et al. (Bonnechere et al.

2 2011). Briefly, ETU was extracted from the homogenized melon (10 g), after thawing of this

3 sample, by a 3:1 mixture of methanol-water. After $0.2 \mu \mathrm{m}$ filtration, the extract containing

$4 \quad 0.333 \mathrm{~g}$ matrix per $\mathrm{mL}$ was injected in LC-MS/MS (conditions in Table 2) on a Uptisphere

5 5MM1 mixed-mode chromatographic column $(100 \times 2.1 \mathrm{~mm}, 5 \mu \mathrm{m})$ with two different silanes

6 (C8/SCX) bonded on silica (Interchim, Montluçon, France), using an isocratic mobile phase 7 of $0.1 \%$ trifluoroacetic acid / methanol (95/5). The injection volume was $5 \mu \mathrm{L}$ in full loop and 8 the run time was 2 min.

9

10 Analysis of melamine by LC-MS/MS

11 The method of analysis is described in a paper of Goscinny et al. (Goscinny et al. 2011).

12 The extraction of melamine is carried out using an acetonitrile-water-dichloromethane in an 13 acidic environment. After SPE and $0.2 \mu \mathrm{m}$ filtration, the extract was injected in LC-MS/MS 14 (conditions in Table 2) on a Acquity HILIC column $(100 \times 2.1 \mathrm{~mm}, 1.7 \mu \mathrm{m})$ (Waters, Ireland), 15 using an isocratic mobile phase containing $2 \%$ ammonium acetate $0.5 \mathrm{M}, 8 \%$ water and $90 \%$ 16 of acetonitrile. The injection volume was $1 \mu \mathrm{L}$ and the run time was $2 \mathrm{~min}$.

19 Limits of Quantification (LOQ) were estimated from the lowest calibration level. Based 20 on the signal-to-noise ratio upper or equal to 6 , LOQs were at $40 \mu \mathrm{g} \mathrm{kg}^{-1}$ for maneb, $2 \mu \mathrm{g} \mathrm{kg}^{-1}$ 21 for imazalil, $5 \mu \mathrm{g} \mathrm{kg}{ }^{-1}$ for cyromazin, $2 \mu \mathrm{g} \mathrm{kg}^{-1}$ for thiamethoxam, and $1 \mu \mathrm{g} \mathrm{kg}^{-1}$ for 22 acetamiprid and carbendazim, $50 \mu \mathrm{g} \mathrm{kg}^{-1}$ for ETU and $25 \mu \mathrm{g} \mathrm{kg}^{-1}$ for melamine. The linearity 23 of the instrument was evaluated with 5 or 6 points in the range of $50-1000 \mu \mathrm{gg}^{-1}$ (wet 24 weight basis) for ETU, 25-600 $\mu \mathrm{g} \mathrm{kg}^{-1}$ for melamine, $50-5000 \mu \mathrm{g} \mathrm{kg}^{-1}$ for maneb and 10-1000 
$1 \mu \mathrm{g} \mathrm{kg}^{-1}$ for the pesticide residues analyzed by LC-MS/MS. In all cases, good linearity was

2 achieved with correlation coefficients $>0.995$.

3 For each batch of analysis, a control (a blank of melon) and a sample were spiked prior to 4 extraction and run. In the control, no pesticide must be found with a concentration greater

5 than the LOQ. If it is not the case that means a contamination and the analysis of the samples

6 must be redone. The spiked sample must have recovery of extraction between $70 \%$ and $120 \%$

7 (SANCO/10684/2009) and the concentrations found in this sample were reported on the 8 control chart, which allows following the trend. Recoveries during the analysis of melon were 9 of $95.7 \%$ for ETU, $73.2 \%$ for maneb, $83.4 \%$ for melamine, $87.3 \%$ for cyromazin, $87.3 \%$ for 10 acetamiprid, $84.0 \%$ for carbendazim and $83.4 \%$ for imazalil. The calibration was checked 11 using a standard injected at the end of the sequence and could not deviate by more than $20 \%$ 12 from the injection of the same standard at the beginning of the sequence.

\section{Calculation of processing factors}

15 Processing factors (PFs) were calculated for all transformation steps by a ratio between 16 the pesticide residue concentration $\left(\mathrm{mg} \mathrm{kg}^{-1}\right)$ in the processed commodity and the pesticide 17 residue concentration $\left(\mathrm{mg} \mathrm{kg}^{-1}\right)$ in the raw commodity.

\section{Results and discussion} raw product were observed for thiamethoxam and carbendazim (Table 3). Thiamethoxam was applied at the lowest concentration in this study and carbendazim is the only which was

25 applied once, as early as the opening of the main stem (Table 1). 
1 In this study, the peeling was done with a knife. Table 4 represents all processing factors

2 for the peeling step for the six detected pesticides for both varieties. The peeling removed an

3 important part of the pesticide residues between $62 \%$ and $95 \%$ for melon Mohican and 4 between $52 \%$ and $95 \%$ for melon Pancha.

5 Maneb and cyromazin are contact pesticides and form deposit on the surfaces of leaves

6 and fruits (Table 4). After the peeling step, in spite of an important reduction for the maneb 7 (91\% for Mohican and 93\% for Pancha), the decrease of cyromazin did not exceed 62\% and $852 \%$ for Mohican and Pancha respectively. However this smaller reduction could be 9 explained by the higher solubility of cyromazin compared with the other pesticides (Table 4).

10 Compounds applied to the plants (leaves) do not have to cross the symplast to arrive in the 11 xylem contrary to compounds passing by roots. On the other hand, they have to cross the 12 more or less waxy cuticle according to the type of plant and the age. With the age, fractures in 13 the waxy coat form hydrophilic pores allowing the passage of the most hydrophilic molecules 14 as cyromazin (Al-Sayeda 2007). With this particularity, cyromazin could enter in the fruit by 15 the flow of xylem and be found in the flesh. As Krol et al. has also confirmed it is possible 16 that pesticide residues are incorporated into plant tissue proportional to the time they remain 17 on biologically active crops in the field. This may even be true of pesticides that are not 18 specifically labelled as systemic (Krol et al. 2000). The other four pesticides (acetamiprid, 19 carbendazim, imazalil and thiamethoxam) are systemic. Nevertheless, acetamiprid and 20 imazalil were strongly reduced by $91 \%$ for Mohican, $89 \%$ for Pancha and $91 \%$ for Mohican 21 and Pancha respectively. The reduction was somewhat less important for the thiamethoxam $22(67 \% \& 58 \%)$ and carbendazim (63\% \& 47\%) (Table 4). The difference of behaviour could 23 be explained by the time of application of these 4 active substances (Table 1). Indeed, 24 carbendazim was the first pesticide applied when the plant of melons had it's 5th flower open 25 on main stem. With this early application, carbendazim could enter in the plant and was 11 
1 present in it before the apparition of fruit. The others were applied in the latest stage of

2 development when $10 \%$ of fruits showed typical fully ripe color (Table 1). Otherwise,

3 thiamethoxam has a good solubility and an octanol-water partition coefficient which allow

4 him at the same time to circulate in the phloem and in the xylem and consequently to be

5 present in the fruit (Table 4). On one hand, more than $90 \%$ of acetamiprid, imazalil and

6 maneb, contact as well systemic pesticides, were removed with this process. On the other

7 hand, $\sim 50 \%$ of carbendazim and thiamethoxam (systemic pesticide) and cyromazin (contact

8 pesticide) were eliminated. These 2 types of reduction could not be explained by the systemic

9 character of the pesticides. However, the agricultural practices (time of application) and the

10 water solubility could explain statistically these differences between the pesticides. The

11 octanol-water partition coefficient is also necessary to explain the behaviour of cyromazin. It

12 is a particular case, not shown in the statistical test which is a global approach. Indeed a

13 systemic pesticide applied late on the plants is found with a low concentration in the flesh.

14 Until now, several studies have explained processing factor with the physico-chemical

15 properties but they did not reflect the moments of application on the harvest (Rasmusssen et

16 al. 2003, Burchat et al. 1998, Watts et al. 1974, Lee et al. 2009). These results show that it

17 really important to take into account the time of application of active substances for the risk

18 assessment. Indeed as Krol (2000) said, a systemic pesticide applied late could not act as a

19 systemic. For risk assessment, it is also necessary to be aware that the levels of residues in

20 melons depend on the time of application quite as the statistical test reflects it.

21 Reductions of $90 \%$ are consistent with previous studies on the peeling of various fruit and 22 vegetables (Balinova et al. 2006, Boulaid et al. 2005, Chavarri et al. 2005, Kaushik et al. 23 2009, Lentza-Rizos \& Balokas 2001, Rasmusssen et al. 2003, Schattenberg et al. 1996, 24 Timme \& Walz-Tylla 2004, Fernandez-Cruz et al. 2006). It was indeed demonstrated that a 25 majority of the insecticides or fungicides applied directly to crops undergo very limited 12 
1 movement or penetration of the cuticle. However, residues of these materials are confined to

2 the outer surfaces where they are amenable to removal by peeling (Holland et al. 1994,

3 Timme \& Walz-Tylla 2004, Burchat et al. 1998).

4 In this study, we also investigated the degradation products of cyromazin and maneb,

5 being melamine and ethylenethiourea (ETU), respectively. In the unprocessed melon, these

6 two by-products were not detected (Table 3). In general, ETU is formed in an acidic, heated

7 environment and it is not the case with the peeling (Dubey et al. 1997, Hwang et al. 2003,

8 Kontou et al. 2001, Sottani et al. 2003).

9 If we compare the concentrations applied on the plants and the concentrations found in

10 melon, there is high variability between the active substances under investigation (Table 1).

11 For example, the concentration in maneb applied on plants was more than 50 times higher

12 than the concentration in cyromazin. The concentration retrieved in the melons (Table 3)

13 showed that the concentration in maneb is 1.5 times lower than for cyromazin. However, the

14 correlation of the results of both varieties was good.

15 Mass balance recoveries were calculated to compare the total $\mathrm{mg}$ of each pesticide in the

16 whole commodity to the residue in the flesh and peels after peeling. Measured concentrations

17 available in Table 4 were corrected with the mass of the whole melons, the flesh and peels

18 comminuted to obtain reconstituted samples. Taking account the measured uncertainties, the

19 measured concentration and calculated concentration were close, as shown in Table 5, The

20 Table 6 showed all corrected PFs. These PFs shows some difference between varieties. An

21 explanation could be the difference of size between both varieties. The proportion peels/flesh

22 is more important and engenders variations between the PFs of both varieties for certain 23 pesticides.

24

25

13 
1

2

3

4

5

6

8

10

\section{Conclusion}

2 During this study, processing factors for peeling of melons were determined for 3 acetamiprid, carbendazim, cyromazin, imazalil, maneb and thiamethoxam. Mechanical

4 peeling, a typical household process, will remove 52 to $91 \%$ of the pesticides on the melon.

5 The reduction of the pesticides could not be fully explained by the systemic character of the

6 pesticides. However, the agricultural practices (time of application), the solubility and mode

7 of action (systemic vs. contact pesticide) of the pesticides allowed to make assumptions to

8 explain the difference in processing factors for the studied pesticides.

9 Two degradation products (melamine and ETU) with a higher toxicity than the parent 10 compounds were also studied and were not detected before and after peeling.

\section{Acknowledgement}

13 This study was funded by the Belgian Federal Public Service of Health, Food Chain Safety 14 and Environment (contract RT 08/3 PESTRANS). We extend our grateful thanks to Redebel 15 for setting up field trials to obtain commodities, to Martine Deridder and Marie-Anne Van 16 den Bergh for their help during the analysis of the samples. 
1 References

2

3 Al-Sayeda H. (2007). Transfert d'un insecticide systémique, l'imidaclopride, chez la tomate:

4 implication du transport phloémien.

5 AND International. 2010. Normes de commercialisation dans le secteur des fruits et légumes.

6 Balinova AM, Mladenova RI, \& Shtereva DD. 2006. Effects of processing on pesticide residues in peaches intended for baby food. Food Addit.Contam. 23(9): 895-901.

Berrada H, Fernandez M, Ruiz MJ, Molto JC, \& Font G. 2010. Surveillance of pesticide residues in fruits from Valencia during twenty months (2004/05). Food Control. 21(1): $36-44$.

Bonnechere, A., Hanot, V., \& Van Loco, J. A rapid and environmental friendly determination of the dithiocarbamates metabolites ethylenethiourea and propylenethiourea in fruit and vegetables by ultra high performance liquid chromatography tandem mass spectrometry. J. Chromatogr. A. 1218(29):4627-4631.

Burchat CS, Ripley BD, Leishman PD, Ritcey GM, Kakuda Y, \& Stephenson GR. 1998. The distribution of nine pesticides between the juice and pulp of carrots and tomatoes after home processing. Food Addit. and Contam. 15(1): 61-71. during commercial processing. Int. J. Food Sci. Tech. 40(2): 205-211. 15 
1 Chen C, Qian Y, Chen Q, Tao C, Li C, \& Li Y. 2011. Evaluation of pesticide residues in 2 fruits and vegetables from Xiamen, China. Food Control. 22(1114-1120.

3 Claeys WL, Schmit JF, Bragard C, Maghuin-Rogister G, Pussemier L, \& Schiffers B. 2011.

4 Exposure of several Belgian consumer groups to pesticide residues through fresh fruit 5 and vegetable consumption. Food Control. 22(3-4): 508-516.

6 de Kok. Developments in GC-MS(/MS) and LC-MS(/MS), Methodology for pesticide residue

7 analysis [Internet]. Rome. Available from:

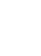
http://workshop.iss.it/DiMuccioV/Testi/Relazioni/adekok.ppt

Dubey JK, Heberer T, \& Stan HJ. 1997. Determination of ethylenethiourea in food commodities by a two-step derivatization method and gas chromatography with electron-capture and nitrogen-phosphorus detection. J. Chromatogr. A. 765(1): 31-38.

European Committee for Standardization. 1998. Final Draft prEN 12396-1, prEN 12396-2, prEN 12396-3; Non-fatty foods - Determination of dithiocarbamate and thiuram disulfide residues.

FASFC. 2007. Controls of pesticide residues in food Belgium 2006. Brussels (Belgium)

FASFC. 2008. Controls of pesticide residues in food Belgium 2007. Brussels (Belgium)

Fernandez-Cruz ML, Grimalt S, Villarroya M, Lopez FJ, Llanos S, \& Garcia-Baudin JM. 2006. Residue levels of captan and trichlorfon in field-treated kaki fruits, individual versus composite samples, and after household processing. Food Addit. and Contam. 23(6): 591-600. 
1 Food and agriculture organization of the United Nations (FAO). FAOSTAT [Internet].

2

3 Goscinny S, Hanot V, Halbardier J-F, Michelet J-Y, \& Van Loco J. 2011. Rapid analysis of 4 5 melamine residue in milk, milk products, bakery goods and flour by ultra-performance liquid chromatography/tandem mass spectrometry: From food crisis to accreditation. Food Control. 22( 226-230).

Granby K, Andersen JH, \& Christensen HB. 2004. Analysis of pesticides in fruit, vegetables and cereals using methanolic extraction and detection by liquid chromatographytandem mass spectrometry. Analytica Chimica Acta. 520(1-2): 165-176.

Holland PT, Hamilton D, Ohlin B, \& Skidmore MW. 1994. Effects of storage and processing on pesticide residues in plant products. Pure Appl. Chem. 66(2): 335-356.

Hwang ES, Cash JN, \& Zabik MJ. 2003. Determination of degradation products and pathways of mancozeb and ethylenethiourea (ETU) in solutions due to ozone and chlorine dioxide treatments. J.Agric.Food Chem. 51(5): 1341-1346.

Kaushik G, Satya S, \& Naik SN. 2009. Food processing a tool to pesticide residue dissipation - A review. Food Res.Int. 42( 26-40.

Keikotlhaile BM, Spanoghe P, \& Steurbaut W. 2010. Effects of food processing on pesticide residues in fruits and vegetables: A meta-analysis approach. Food Chem.Toxicol. 48(1): $1-6$.

Keinath AP, Holmes GJ, Everts KL, Egel DS, \& Langston J. 2007. Evaluation of combinations of chlorothalonil with azoxystrobin, harpin, and disease forecasting for 
control of downy mildew and gummy stem blight on melon. Crop Protection. 26(2):

2 83-88.

3

4

5

6

Kontou S, Tsipi D, Oreopoulou V, \& Tzia C. 2001. Determination of ETU in tomatoes and tomato products by HPLC-PDA. Evaluation of cleanup procedures. J.Agric.Food Chem. 49(3): 1090-1097.

Krol WJ, Arsenault TL, Harry M, \& Incorvia Mattina MJ. 2000a. Reduction of Pesticide Residues on Produce by Rinsing. J.Agric.Food Chem. 48(10): 4666-4670.

Lee MG \& Jung D. 2009. Processing factors and removal ratios of select pesticides in hot pepper leaves by a successive process of washing, blanching, and drying. Food Sci. Biotechnol. 18(5): 1078-1082.

Lentza-Rizos C \& Balokas A. 2001a. Residue levels of chlorpropham in individual tubers and composite samples of post-harvest treated potatoes. J.Agric.Food Chem. 49: 710-714.

Lewis DJ, Thorpe SA, \& Reynolds SL. 1996. The carry-through of residues of thiabendazole, tecnazene and chlorpropham from potatoes following manufacture into potato crisps and jacket potato crisps. Food Addit. Contam. 13(2): 221-229.

Ling Y, Wang H, Yong W, Zhang F, Sun L, Yang ML, Wu YN, \& Chu XG. 2011. The effects of washing and cooking on chlorpyrifos and its toxic metabolites in vegetables. Food Control. 22(1): 54-58.

Randhawa MA, Anjum FM, Asi MR, Butt MS, Ahmed A, \& Randhawa MS. 2007. Removal of endosulfan residues from vegetables by household processing. J. Sci. Ind. Res. 66(10): 849-852. 
1 Rasmusssen RR, Poulsen ME, \& Hansen HC. 2003. Distribution of multiple pesticide

2

3

4

5

6

7 residues in apple segments after home processing. Food Addit.Contam. 20(11): 10441063.

SANCO/10684/2009. Method validation and quality control procedures for pesticide residues $\begin{array}{lllll}\text { analysis } & \text { in } & \text { food } & \text { and }\end{array}$ http://ec.europa.eu/food/plant/protection/resources/qualcontrol_en.pdf

Schattenberg HJ, Geno PW, Hsu JP, Fry WG, \& Parker RP. 1996. Effect of household preparation on levels of pesticide residues in produce. J. AOAC Int. 79(6): 1447-1453.

Sottani C, Bettinelli M, Fiorentino ML, \& Minoia C. 2003. Analytical method for the quantitative determination of urinary ethylenethiourea by liquid chromatography/electrospray ionization tandem mass spectrometry. Rapid Commun.Mass Spectrom. 17(20): 2253-2259.

Timme G \& Walz-Tylla B (2004). Effects of food preparation and processing on pesticide residues in commodities of plant origin. In Denis Hamilton \& Stephen Crossley (Ed.), Pesticides residues in food and drinking water: human exposure and risks (pp. 121148). John Wiley \& Sons.

Tong-Xian L. 2004. Toxicity and efficacy of spiromesifen, a tetronic acid insecticide, against sweetpotato whitefly (homoptera: aleyrodidae) on melons and collards. Crop Protection. 23(6): 505-513.

Watts RR, Storherr RW, \& Onley JH. 1974. Effects of cooking on ethylenebisdithiocarbamate degradation to ethylenethiourea. B. Environ. Contam. Tox. 12(2): 224-226. 


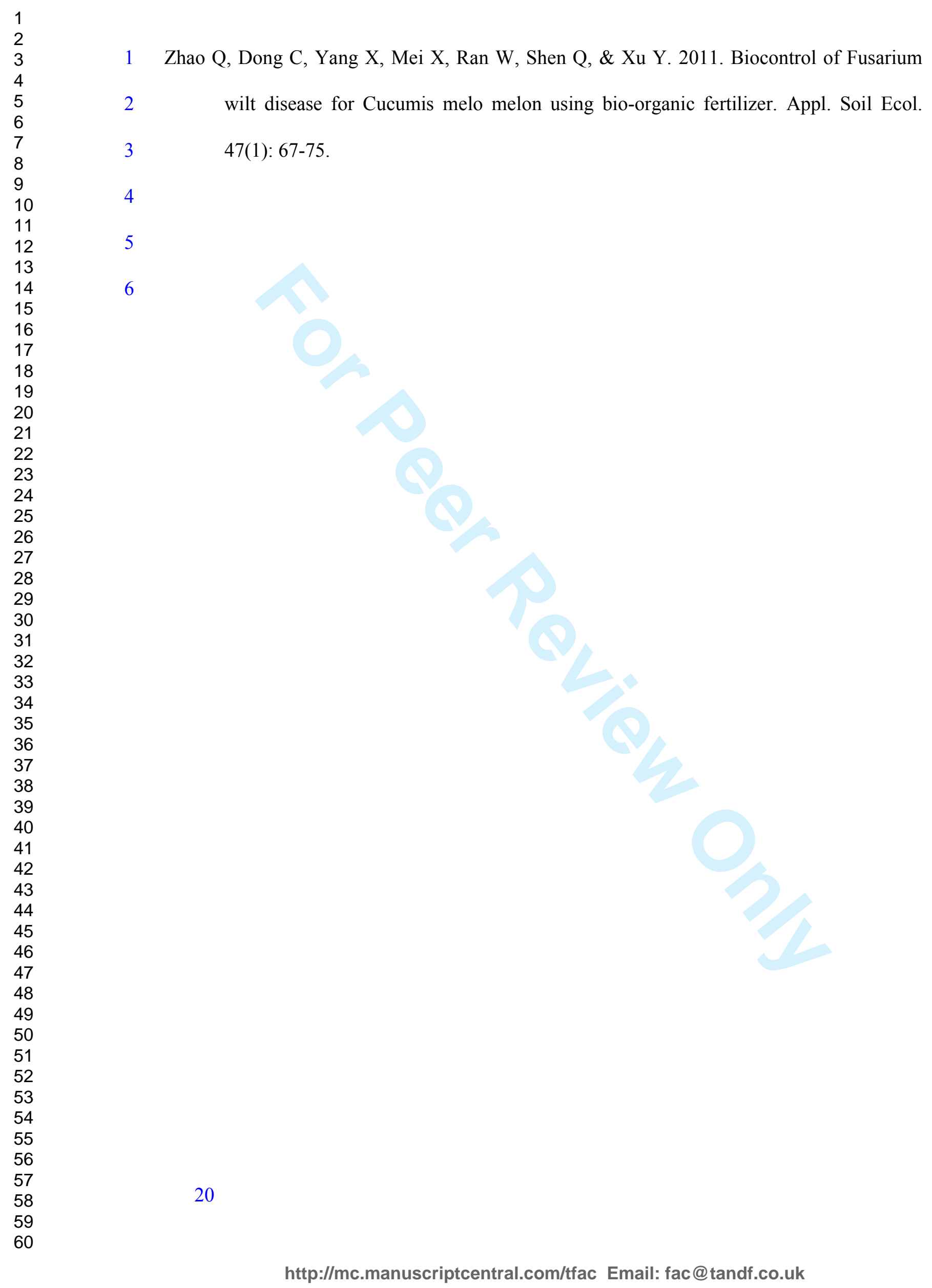

http://mc.manuscriptcentral.com/tfac Email: fac@tandf.co.uk 
1

2

3

4

5

6

7

8

9

10

11

12

13

14

15

16

17

18

19

20

21

22

23

24

25

26

27

28

29

30

31

32

33

34

35

36

37

38

39

40

41

42

43

44

45

46

47

48

49

50

51

52

53

54

55

56

57

58

59

60

\section{Figure Caption}

2 Figure 1: Flow diagram of processing steps and sampling for one variety of melon. 3

4 


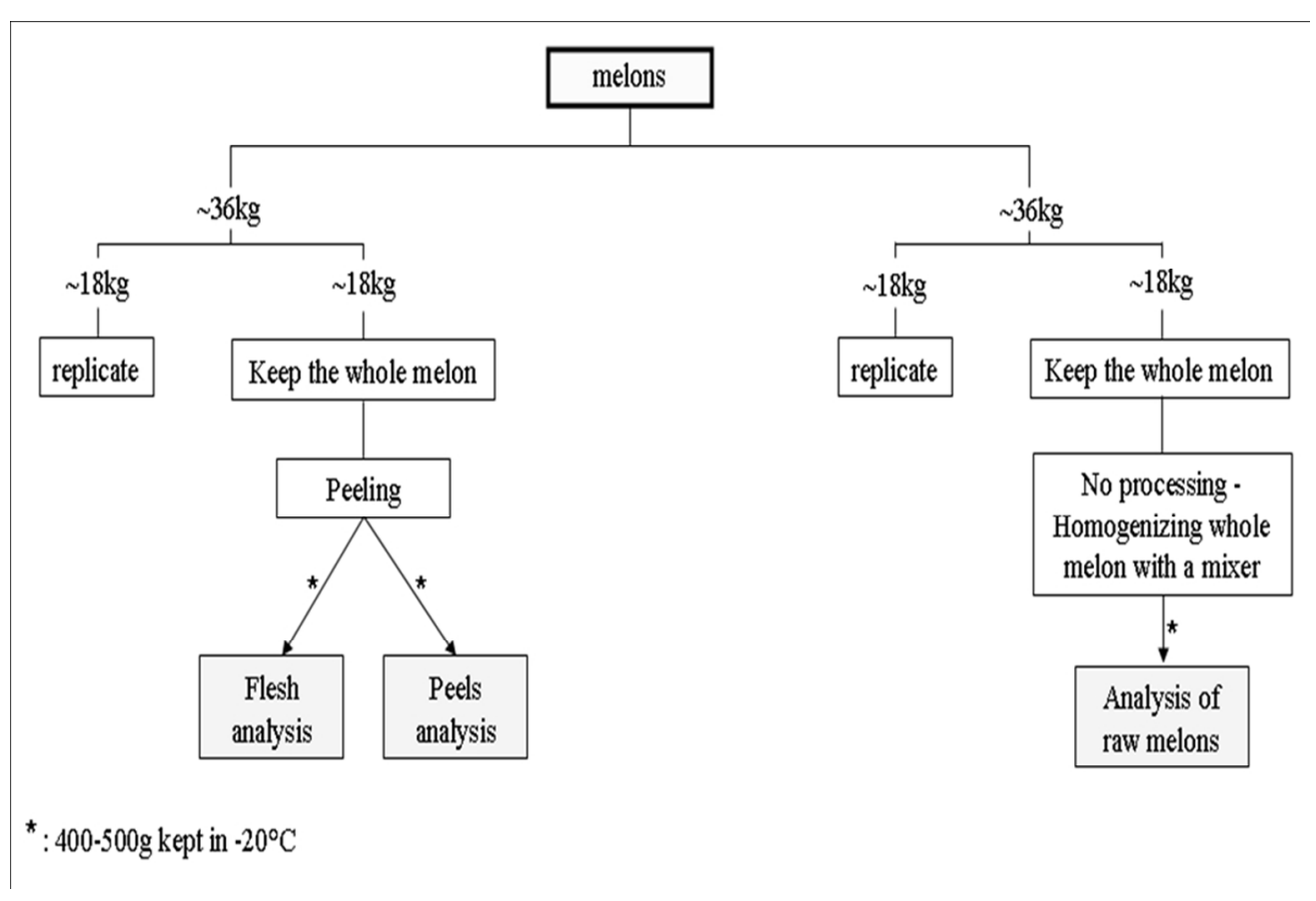

Figure 1: Flow diagram of processing steps and sampling for one variety of melon. $90 \times 60 \mathrm{~mm}(300 \times 300 \mathrm{DPI})$ 
Table 1: Pesticides with their product name, rate of application and the crop stage at the moment of application

\begin{tabular}{|c|c|c|c|c|c|c|}
\hline Pesticides & Product Name & $\begin{array}{c}\text { Active } \\
\text { ingredient } \\
\left(\mathrm{g} \mathrm{ha}^{-1}\right)\end{array}$ & $\begin{array}{l}\text { Application } \\
\text { date }\end{array}$ & Crop Stage $\left(\mathbf{B B C H}^{\mathrm{a}}\right)$ & $\begin{array}{c}\text { Number of } \\
\text { days before } \\
\text { harvest }\end{array}$ & $\begin{array}{c}\text { MRL } \\
(\mathbf{m g} / \mathbf{k g})\end{array}$ \\
\hline \multirow[t]{2}{*}{ Acetamiprid } & Gazelle SP & 105 & $9 / 08 / 2010$ & $\begin{array}{l}\text { BBCH } 83=30 \% \text { of fruits show typical fully ripe colour } \\
\text { (FTRC) }\end{array}$ & 10 & $0.01^{*}$ \\
\hline & & 98 & $16 / 08 / 2010$ & $\mathrm{BBCH} 87=70 \%$ FTRC & 3 & \\
\hline Carbendazim & Punch SE & 319 & $5 / 07 / 2010$ & $\mathrm{BBCH} 65=5$ th flower open on main stem & 45 & $0.1 *$ \\
\hline \multirow[t]{3}{*}{ Cyromazine } & Trigard $100 \mathrm{SL}$ & 58 & $2 / 08 / 2010$ & BBCH $81=10 \%$ FTRC & 17 & 0.3 \\
\hline & & 63 & $9 / 08 / 2010$ & $\mathrm{BBCH} 83=30 \%$ FTRC & 10 & \\
\hline & & 59 & $16 / 08 / 2010$ & BBCH $87=70 \%$ FTRC & 3 & \\
\hline \multirow[t]{3}{*}{ Imazalil } & Fungaflor EC & 97 & $2 / 08 / 2010$ & $\mathrm{BBCH} 81=10 \%$ FTRC & 17 & 2 \\
\hline & & 105 & $9 / 08 / 2010$ & $\mathrm{BBCH} 83=30 \%$ FTRC & 10 & \\
\hline & & 98 & $16 / 08 / 2010$ & $\mathrm{BBCH} 87=70 \%$ FTRC & 3 & \\
\hline \multirow[t]{3}{*}{ Maneb } & Trimangol $75 \mathrm{WG}$ & 1950 & $2 / 08 / 2010$ & $\mathrm{BBCH} 81=10 \%$ FTRC & 17 & 1 \\
\hline & & 2108 & $9 / 08 / 2010$ & $\mathrm{BBCH} 83=30 \%$ FTRC & 10 & \\
\hline & & 1971 & $16 / 08 / 2010$ & $\mathrm{BBCH} 87=70 \%$ FTRC & 3 & \\
\hline \multirow[t]{3}{*}{ Thiamethoxam } & Actara $25 \mathrm{WG}$ & 5 & $2 / 08 / 2010$ & BBCH $81=10 \%$ FTRC & 17 & 0.2 \\
\hline & & 5 & 9/08/2010 & $\mathrm{BBCH} 83=30 \%$ FTRC & 10 & \\
\hline & & 5 & $16 / 08 / 2010$ & $\mathrm{BBCH} 87=70 \%$ FTRC & 3 & \\
\hline
\end{tabular}

${ }^{\mathrm{a}}$ The BBCH-scale is a system for a uniform coding of phenologically similar growth stages of all mono- and dicotyledonous plant species.

* Indicates lower limit of analytical determination (Reg. (EU) No 600/2010)

Italics characters indicate that these substances are not authorized on melon in Belgium 
Table 2

MS detection and selected ion for multi-residues analysis by LC-MS/MS. Quantifier daughter ions are in bold.

\begin{tabular}{|c|c|c|c|c|c|c|c|c|}
\hline MS detection & & & & & & & & \\
\hline Extractor (V) & 4 & & & & & & & \\
\hline RF Lens (V) & 0.2 & & & & & & & \\
\hline $\begin{array}{l}\text { Cone Gas Flow } \\
(\mathrm{L} / \mathrm{Hr})\end{array}$ & 50 & & & & & & & \\
\hline $\begin{array}{l}\text { Desolvation Gas } \\
\text { Flow (L/Hr) }\end{array}$ & 800 & & & & & & & \\
\hline Selected Ion & $\begin{array}{c}\text { Parents } \\
(\mathrm{m} / \mathrm{z})\end{array}$ & $\begin{array}{c}\text { Daughter } \\
(\mathrm{m} / \mathrm{z})\end{array}$ & $\begin{array}{l}\text { Capillary } \\
(\mathrm{kV})\end{array}$ & $\begin{array}{c}\text { Source } \\
\text { Temperature }\left({ }^{\circ} \mathrm{C}\right) \\
\end{array}$ & $\begin{array}{c}\text { Desolvation } \\
\text { Temperature }\left({ }^{\circ} \mathrm{C}\right) \\
\end{array}$ & $\begin{array}{l}\text { Cone } \\
(\mathrm{V})\end{array}$ & $\begin{array}{c}\text { Collision } \\
(\mathrm{V})\end{array}$ & $\begin{array}{l}\text { Retention time } \\
(\mathrm{min})\end{array}$ \\
\hline Cyromazin & 167.01 & $\begin{array}{l}84.9 \\
60.3\end{array}$ & 0.6 & 130 & 400 & 28 & $\begin{array}{l}16 \\
18\end{array}$ & 1.53 \\
\hline Thiamethoxam & $\begin{array}{l}292.3 \\
294.3\end{array}$ & $\begin{array}{l}\mathbf{2 1 1 . 0} \\
180.9 \\
211.0\end{array}$ & 0.6 & 130 & 400 & $\begin{array}{l}19 \\
19\end{array}$ & $\begin{array}{l}12 \\
24 \\
12\end{array}$ & 2.49 \\
\hline Acetamiprid & 223.0 & $\begin{array}{c}\mathbf{1 2 5 . 8} \\
89.9\end{array}$ & 0.6 & 130 & 400 & 26 & $\begin{array}{l}21 \\
35\end{array}$ & 3.65 \\
\hline Carbendazim & 192.1 & $\begin{array}{l}\mathbf{1 6 0 . 1} \\
132.1\end{array}$ & 0.6 & 130 & 400 & 25 & $\begin{array}{l}18 \\
30\end{array}$ & 3.92 \\
\hline Oxfendazole & 316.0 & 159.0 & 0.6 & 130 & 400 & 34 & 28 & 5.35 \\
\hline Imazalil & 297.1 & $\begin{array}{c}\mathbf{1 5 9 . 0} \\
69.1\end{array}$ & 0.6 & 130 & 400 & 30 & $\begin{array}{l}20 \\
20\end{array}$ & 8.67 \\
\hline ETU & 102.9 & $\begin{array}{l}\mathbf{4 4 . 3} \\
85.9\end{array}$ & 0.3 & 130 & 450 & 31 & $\begin{array}{l}15 \\
15\end{array}$ & 0.91 \\
\hline ETU D4 & 106.9 & $\begin{array}{l}45.1 \\
\mathbf{4 8 . 2} \\
\end{array}$ & 0.3 & 130 & 450 & 31 & $\begin{array}{r}15 \\
15 \\
\end{array}$ & 0.89 \\
\hline Melamine & 126.9 & $\begin{array}{l}\mathbf{8 4 . 8} \\
67.8 \\
\end{array}$ & 0.8 & 150 & 400 & 42 & $\begin{array}{l}22 \\
17\end{array}$ & 0.91 \\
\hline
\end{tabular}


Table 3

Concentrations $\left(\mathrm{mg} \mathrm{kg}^{-1}\right)$ of pesticides and degradation products for the two melon varieties after peeling step. Mean values $( \pm \mathrm{SD}, \mathrm{n}=2)$ of two melon batches are depicted.

\begin{tabular}{|c|c|c|c|c|}
\hline Pesticides & $\begin{array}{c}\text { LOQ } \\
(\mathrm{mg} / \mathrm{kg})\end{array}$ & $\begin{array}{c}\text { Raw } \\
\text { Mean values }( \pm \text { SD })\end{array}$ & $\begin{array}{c}\text { Flesh } \\
\text { Mean values }( \pm \text { SD) }\end{array}$ & $\begin{array}{c}\text { Peels } \\
\text { Mean values }( \pm \text { SD })\end{array}$ \\
\hline Acetamiprid & 0.001 & $0.042( \pm 0.00057)$ & $0.0039( \pm 0.00007)$ & $0.081( \pm 0.0087)$ \\
\hline Carbendazim & 0.001 & $0.0014( \pm 0.00049)$ & $<$ LOQ & $0.0042( \pm 0.0018)$ \\
\hline Cyromazin & 0.005 & $0.078( \pm 0.0022)$ & $0.029( \pm 0.0031)$ & $0.110( \pm 0.0024)$ \\
\hline Imazalil & 0.002 & $0.0092( \pm 0.00085)$ & $<\mathrm{LOQ}$ & $0.017( \pm 0.0039)$ \\
\hline Maneb & 0.040 & $0.48( \pm 0.075)$ & $0.043( \pm 0.032)$ & $0.82( \pm 0.086)$ \\
\hline Thiamethoxam & 0.002 & $0.0045( \pm 0.0000)$ & $<\mathrm{LOQ}$ & $0.0074( \pm 0.0003)$ \\
\hline ETU & 0.050 & $<$ LOQ & $<$ LOQ & $<\mathrm{LOQ}$ \\
\hline Melamine & 0.025 & $<\mathrm{LOQ}$ & $<$ LOQ & $<$ LOQ \\
\hline
\end{tabular}

Variety 2: Pancha

\begin{tabular}{lcccc}
\hline Pesticides & $\begin{array}{c}\text { LOQ } \\
(\mathbf{m g} / \mathbf{k g})\end{array}$ & $\begin{array}{c}\text { Raw } \\
\text { Mean values }( \pm \text { SD })\end{array}$ & $\begin{array}{c}\text { Flesh } \\
\text { Mean values }( \pm \text { SD })\end{array}$ & $\begin{array}{c}\text { Peels } \\
\text { Mean values }( \pm \text { SD })\end{array}$ \\
\hline Acetamiprid & 0.001 & $0.046( \pm 0.0029)$ & $0.0051( \pm 0.0018)$ & $0.083( \pm 0.00092)$ \\
Carbendazim & 0.001 & $0.0012( \pm 0.00021)$ & $<$ LOQ & $0.0034( \pm 0.00014)$ \\
Cyromazin & 0.005 & $0.081( \pm 0.013)$ & $0.039( \pm 0.0026)$ & $0.084( \pm 0.00064)$ \\
Imazalil & 0.002 & $0.011( \pm 0.00014)$ & $<$ LOQ & $0.017( \pm 0.0032)$ \\
Maneb & 0.040 & $0.55( \pm 0.050)$ & $<$ LOQ & $0.91( \pm 0.062)$ \\
Thiamethoxam & 0.002 & $0.0036( \pm 0.0003)$ & $<$ LOQ & $0.0074( \pm 0.0001)$ \\
ETU & 0.050 & $<$ LOQ & $<$ LOQ & $<$ LOQ \\
Melamine & 0.025 & $<$ LOQ & $<$ LOQ & $<$ LOQ \\
\hline
\end{tabular}


2

Table 4: Mean values $( \pm S D, n=2)$ of processing factors $(P F)$ for peeling step for six pesticides in two varieties of melons.

\begin{tabular}{|c|c|c|c|c|c|}
\hline \multirow{2}{*}{ Pesticides } & \multicolumn{2}{|c|}{ PF peeling $( \pm S D)$} & \multirow[t]{2}{*}{ Action mode } & \multirow{2}{*}{$\begin{array}{l}\text { log-octanol- } \\
\text { water- } \\
\text { partitioning } \\
\text { coefficients }\end{array}$} & \multirow[t]{2}{*}{$\begin{array}{l}\text { Water solubility } \\
\text { at } 20^{\circ} \mathrm{C}(\mathrm{mg} / \mathrm{L})\end{array}$} \\
\hline & Mohican & Pancha & & & \\
\hline Acetamiprid & $0.091( \pm 0.002)$ & $0.11( \pm 0.040)$ & Systemic & 0.8 & 2950 \\
\hline Carbendazim & $0.37( \pm 0.14)$ & $0.43( \pm 0.08)$ & Systemic & 1.48 & 8 \\
\hline Cyromazin & $0.38( \pm 0.04)$ & $0.48( \pm 0.08)$ & Non systemic & 0.069 & 13000 \\
\hline Imazalil & $0.11( \pm 0.010)$ & $0.093( \pm 0.001)$ & Systemic & 3.82 & 22.4 \\
\hline Maneb & $0.088( \pm 0.068)$ & $0.073( \pm 0.007)$ & Non systemic & -0.45 & 178 \\
\hline Thiamethoxam & $0.33( \pm 0.16)$ & $0.42( \pm 0.20)$ & Systemic & -0.13 & 4100 \\
\hline
\end{tabular}


Table 5: Active substances (mg) accounting for mass balance of pesticides and degradation products for the two melon varieties after peeling step. Mean values $( \pm S D, n=2)$ of two melon batches are depicted.

Variety 1: Mohican

\begin{tabular}{|c|c|c|c|c|}
\hline \multirow{2}{*}{ Pesticides } & Raw (measured) & Flesh & Peels & Raw (calculated) \\
\hline & Mean values $( \pm \mathrm{SD})$ & Mean values $( \pm \mathrm{SD})$ & Mean values $( \pm \mathrm{SD})$ & Mean values $( \pm \mathrm{SD})$ \\
\hline Acetamiprid & $0.75( \pm 0.058)$ & $0.037( \pm 0.0001)$ & $0.57( \pm 0.084)$ & $0.60( \pm 0.084)$ \\
\hline Carbendazim & $0.024( \pm 0.0073)$ & $0.048( \pm 0.0001)$ & $0.029( \pm 0.014)$ & $0.034( \pm 0.014)$ \\
\hline $\begin{array}{l}\text { Cyromazine } \\
\text { Imazalil }\end{array}$ & $\begin{array}{l}1.38( \pm 0.049) \\
0.16( \pm 0.026)\end{array}$ & $\begin{array}{c}0.281( \pm 0.026) \\
0.010( \pm 0.0001)\end{array}$ & $\begin{array}{l}0.77( \pm 0.014) \\
0.12( \pm 0.032)\end{array}$ & $\begin{array}{c}1.05( \pm 0.04) \\
0.13( \pm 0.032)\end{array}$ \\
\hline Maneb & $8.60( \pm 1.88)$ & $0.41( \pm 0.31)$ & $5.78( \pm 0.84)$ & $6.19( \pm 1.15)$ \\
\hline Thiamethoxam & $0.080( \pm 0.0051)$ & $0.010( \pm 0.013)$ & $0.052( \pm 0.0001)$ & $0.061( \pm 0.013)$ \\
\hline ETU & $<$ LOQ & $<$ LOQ & $<$ LOQ & $<\mathrm{LOQ}$ \\
\hline Mélamine & $<$ LOQ & $<$ LOQ & $<$ LOQ & $<\mathrm{LOQ}$ \\
\hline \multicolumn{5}{|c|}{ Variety 2: Pancha } \\
\hline Pesticides & $\begin{array}{c}\text { Raw } \\
\text { Mean values }( \pm \text { SD) }\end{array}$ & $\begin{array}{c}\text { Flesh } \\
\text { Mean values }( \pm \text { SD) }\end{array}$ & $\begin{array}{c}\text { Peels } \\
\text { Mean values }( \pm \mathrm{SD})\end{array}$ & $\begin{array}{c}\text { Raw (calculated) } \\
\text { Mean values ( } \pm \text { SD) }\end{array}$ \\
\hline Acetamiprid & $0.86( \pm 0.0016)$ & $0.065( \pm 0.025)$ & $0.59( \pm 0.077)$ & $0.653( \pm 0.10)$ \\
\hline Carbendazim & $0.022( \pm 0.0052)$ & $0.0063( \pm 0.0002)$ & $0.024( \pm 0.0019)$ & $0.030( \pm 0.0021)$ \\
\hline Cyromazine & $1.50( \pm 0.15)$ & $0.49( \pm 0.050)$ & $0.59( \pm 0.067)$ & $1.086( \pm 0.12)$ \\
\hline Imazalil & $0.20( \pm 0.015)$ & $0.013( \pm 0.0004)$ & $0.12( \pm 0.037)$ & $0.13( \pm 0.037)$ \\
\hline Maneb & $10.17( \pm 0.31)$ & $0.50( \pm 0.017)$ & $6.46( \pm 1.21)$ & $6.97( \pm 1.23)$ \\
\hline Thiamethoxam & $0.067( \pm 0.0012)$ & $0.019( \pm 0.0095)$ & $0.051( \pm 0.0066)$ & $0.070( \pm 0.016)$ \\
\hline ETU & $<$ LOQ & $<$ LOQ & $<$ LOQ & $<$ LOQ \\
\hline Mélamine & $<$ LOQ & $<$ LOQ & $<$ LOQ & $<\mathrm{LOQ}$ \\
\hline
\end{tabular}


Table 6: Mean values $( \pm \mathrm{SD}, \mathrm{n}=2$ ) with mass balance of processing factors (PF) for peeling step for six pesticides in two varieties of melons.

\begin{tabular}{lcc}
\hline \multirow{2}{*}{ Pesticides } & \multicolumn{2}{c}{ PF peeling $( \pm$ SD $)$} \\
& Mohican & Pancha \\
\hline Acetamiprid & $0.049( \pm 0.0038)$ & $0.075( \pm 0.030)$ \\
Carbendazim & $0.20( \pm 0.062)$ & $0.29( \pm 0.072)$ \\
Cyromazine & $0.20( \pm 0.020)$ & $0.33( \pm 0.046)$ \\
Imazalil & $0.058( \pm 0.0091)$ & $0.063( \pm 0.0051)$ \\
Maneb & $0.048( \pm 0.038)$ & $0.050( \pm 0.0023)$ \\
Thiamethoxam & $0.12( \pm 0.16)$ & $0.29( \pm 0.14)$ \\
\hline
\end{tabular}

